\title{
An analysis of the Chinese techniques and methods in the objects of landscape heritage in the city of Saratov, Russia
}

\author{
$Y u$. Barinov ${ }^{1, *}$, and $O$. Sokolskaya ${ }^{1}$ \\ ${ }^{1}$ Saratov State University named after N. I. Vavilov, 410012, Sovetskaya str., 60, Saratov, Russia
}

\begin{abstract}
In many regions of Russian Federatio, the objects of landscape heritage are in poor condition. They were created between the second half of the 18th century and the beginning of the 20th century. It was the period when landscape park constructions became widespread in Europe and Russia after establishing active trade and industry relations with East Asian countries, such as China. The research includes analysis of Chinese techniques and methods, which emerged in Russian objects of landscaping art, particularly in estate gardens and parks of the Volga region. The main criteria and flora used in "green" architecture in the territories of the landscape heritage objects of Saratov Volga region are discovered. The assessment of the range of greenery introduced from China and of the elements of the park architecture is given.
\end{abstract}

\section{Introduction}

In many regions of Russian Federation the objects of landscape heritage created in the period between the second half of the $18^{\text {th }}$ century and the beginning of the 20th century are in poor condition. That period was the one when, after establishing active trade and industry relations with Far Eastern countries, such as China and Japan, the construction of landscape parks became wide spread in Western Europe and Russia [6, 9].

In this connection, the relevance of topic of our research is determined by the necessity of analysing the techniques and methods which came from the countries of Eastern Asia and Far East and spread throughout the Volga Region, in particular in the territory of the objects of landscaping art in Saratov Region, in order to work out a competent approach to the restoration of such heritage and including it into the process of the recovery of the region.

It is necessary to consider the factors and the rate of influence of Asian and Far Eastern regions along with their popularity and geographical proximity to the Volga Region.

* Corresponding author: yamato@ fromru.com 


\section{Materials and methods}

Objectives of the research: to reveal and estimate the influence of Asian and Far Eastern, Chinese in particular, traditions and techniques on the objects of landscape heritage of Saratov Volga Region.

As the objects of the research we chose the estate parks created in between the end of 18th and the beginning of 20th centuries in the villages Polchaninovka in Tatischevskiy district, Marfino in Atkarskiy district, Pady in Balashovskiy district, Severnyi in Khvalynskiy district etc. situated in Saratov Region. The methods of the research were based on the following principles. (1) The historical principle: the discovering of general patterns in the developing of objects of landscape architecture in the countries of Asia and Far East (China and Japan) and Russia and the Volga Region. The study of archives and local history materials was based on the methods by [10] and [1, 2, 4]. (2) The comparative chronology and development principle: it became possible to track back the emergence and developing of the objects of landscape architecture, the periods of development and the patterns of adopting the methods and techniques of creating the objects of greenery in populated areas of the Volga Region. The study was based on the methods developed in [5, $7,8,10,11]$. (3) The nature observation principle: the layouts, vegetation forms, small architecture forms along with the views perspectives were observed and measured.

\section{Results and discussion}

We distinguished the common features of old estate parks in the Saratov Volga region and their Asian and Far Eastern counterparts. Thus, the research showed that the composition of space in the objects of landscape architecture of the Volga region is similar to the parks in China, which is evident in the planning solutions of such works of "green" architecture. As well as the Chinese parks, the objects of our research are situated close by populated areas (for instance, the estate park of the landed gentleman Minkh in the village of Polchaninovka or a similar estate of the landed gentleman Medem in the village of Severnyi) [5, 8].

It is well known that the layout of a Far Eastern park was based on the principles of reaching the necessary level of comfort with minimum interference into the natural landscape. The objects analyzed in the research are linked with the surrounding nature through adjoining forests and scenic hills (a park in Polchaninovka) or agricultural lands (a park in Severnyi), or a system of ravines and gullies (the Shakhmatovs' estate park in the village of Gubaryovka). Their networks of walks and paths have lots of forks and turns. Chinese parks are characterized by alternation of closed (woodlands) and open (clearings) spaces. Similar enfilades are observed in the studied parks. Groups of objects and woodlands occupy $53 \%$ of space, and clearings occupy $47 \%$.

The main components of Far Eastern parks are hills, stones, and water bodies (lakes, ponds, brooks etc.). The hills were emphasized with pagodas, pavilions etc. In landscape and architecture objects of the Saratov Volga region, especially on the right bank, the uplands are used to hold pavilions with open views in all directions, mostly on water [8]. The colors of their decorations were similar to those of Chinese architecture. The bank lines and slopes of the pools were strengthened with stones as well as the park stairs. A water body in a Chinese park, for instance, "widens and deepens the space doubling the number of compositions by means of reflecting. A lot of famous Chinese parks were formed on the banks of enormous natural lakes" [4]. In the studied objects of landscape architecture, all three parks have water systems: the Polchaninovka park once had a cascade of ponds, which is now a single large pond; Medem's park has a similar construction; the Marfino park has a brook-river with some wide and narrow places. The cascade ponds that once were in the Minkh's park had a stream completed with stones which was connecting them 
all. The murmuring water was flowing among and over the stones going into the large pond, where the reflecting effect of a high bank was putting a visitor into the atmosphere of coolness and calmness, which was close to the Far Eastern traditions. In Marfino, in the park of the landed gentleman Krivitskiy, there is a brook-river that flows through various landscapes and scenes to unite them into a whole.

As for the flora, many of its kinds are from Chinese assortment of the temperate zone of the Northern Province (Hebei, Henan, Shandong, Shanxi, and Gansu), Liaodong Peninsula and, the North China Plain and can be found in the studied objects. In China, this area is an area of deciduous broadleaved forests. Its absolute temperatures vary from $15^{\circ} \mathrm{C}$ in the South up to $30^{\circ} \mathrm{C}$ in the North [2]. Average precipitation is $500-700 \mathrm{~mm}$. The plants imported from this area into the objects of landscaping art in the Volga region were Pinus sylvestris, Thuja orientalis, Catalpa bungei (for modern landscaping), Juniperus chinensis (for modern landscaping), Populus alba L, Caragana arborescens, Syringa amurénsis, Syringa x chinensis Willd, Syringa persica, Syringa pubescens and others.

In Japan, the temperate zone is situated in the mountains at the height of 1000-1500 m above sea level (on the isles of Kyushu and south Shikoku, goes down to the sea side (at about $38^{\circ}$ north latitude) on the isle of Honshu and stretches to the south-east part of Hokkaido). This is an area of deciduous broadleaved forests [4]. From the area such plants as Acer japonicum (for modern landscaping), A. palmatum, Hydrangea paniculata and others were successfully introduced to the Saratov region.

It was common in the Volga Region to plant a pine (Pinus sylvéstris) near a manor house. According to some Chinese beliefs, a pine is a symbol of spiritual purity. Instead of peach trees in Russia, they planted different kinds of plums (Prunus) in Tatischevo parks. A plum is a symbol of happiness. And sakura - the Japanese cherry - was replaced by cherry and bird cherry trees (Prunus padus) in the objects of landscape architecture in our research. There is no doubt that different kinds of willows (Salix) were planted near water bodies just as in China. An English oak (Quercus robus) is not only a symbol of might in Russia, but also a popular tree in the parks of China. The same can be said about different kinds of maples (Acer). Apple trees (Malus) are very characteristic for both gardens of China and Russia, particularly in those of the Volga Region. In China the trees and shrubs are usually planted in groups or even whole groves. Such planting plans were also typical for parks in the Tatischevskiy district.

In traditional parks of China, they prefer the arborescent type of peony, which was considered the king of all flowers [1]. Lotuses, irises, peonies, roses, briars, and chrysanthemums can also be found there. In Russia and in the Volga region, especially in the 19th and early 20th centuries, peonies, roses, briars, and chrysanthemums in autumn were in nearly every nobility estate park ensemble and complex. Lotuses were replaced by water lilies (Nymphaea).

Our research showed that out of different Asian and Far Eastern tendencies, the most characteristic for the Volga Region were the features of park designs of China (84\%).

We discovered the following families of trees and shrubs plantations prevailing in the Volga region in the territories of its historical parks and especially in the estate parks we studied: Leguminosae Juss. (24\%), Salicaceae Mirbu (28\%), Oleaceae Lindl. (17\%), and Rosaceae Juss. (13\%). If the species composition research by E.V. Golosova (2010) showed that "the assortment of plants in Chinese gardens is mainly based on local flora, the number of introduced plants is also low in Japan, though it is higher than in China", gardens and parks in Great Britain contain "only 35\% of local flora and almost the same amount of plant of Chinese origin (32.5\%)", then our assessment of estate landscaped parks has different data. Thus, according to our analysis of the range of plantings in the territories of the Saratov region's objects of landscape heritage, there are less introduced plants than in the British parks, and they have more local flora than it is used in the Chinese and Japanese 
gardens and parks (Figure 1). We assume that it is mostly connected with the climate and nature peculiarities along with the traditions of Russian landscape architecture.

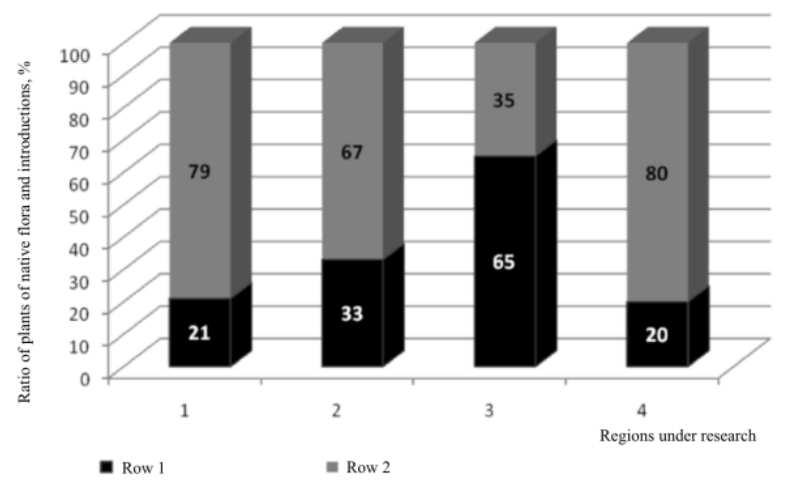

Fig. 1. Percentage of local flora plants and introduced plants in gardens and parks of: 1 - China [4]; Japan [4]; 3 - the Great Britain [4]; 4 - the Saratov Volga region (Russia) [11]. Row 1 - introduced plants; row 2 - local flora plants.

It is characteristic that the ratio of evergreen plantations in the objects of the research is 2 times lower if compared with China and Great Britain and 2,5 times lower if compared with Japan (Figure 2).

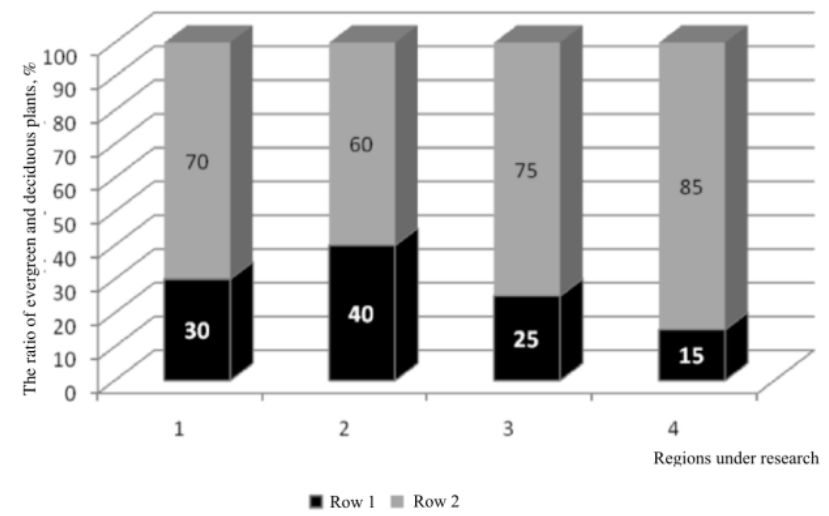

Fig. 2. Percentage of evergreen and deciduous plantations in landscaped flora of: 1 - China [4]; Japan [4]; 3 - the Great Britain [4]; 4 - the Saratov Volga region (Russia) [11]. Row 1 - evergreened plantations; row 2 - deciduous plantations.

Considering all above, it should be mentioned that the measure of layout planning, in particular that of networks of walks and paths, is equal to Chinese pieces of "green" architecture in our objects. The style of the Volga region's landscaped parks constructed in the period between the end of 18th and the beginning of the 20th centuries is based on creating graphic landscapes employing some elements of the Chinese art of gardening.

Small buildings observed in the parks are considerably lower than those in the Chinese parks (by three and more times). Their coloring is more quiet. Nevertheless, such elements exist (or existed) almost everywhere.

It should be noted that imitation of the Chinese style does not reflect a reliable plot. The will of an architect and the romantic dream of relocation into the fairy-tale world are always present. Moving to such a world at the behest of the architect, the guests of the park create 
in their minds a new image, different from the real one. A special role in this can be played by improperly selected plants, unsystematically placed stones, etc.

\section{Conclusions}

Thus, our research allows making some conclusions:

- Some techniques and tendencies characteristic for Asian and Far Eastern park construction also appear as elements of the layouts in estate parks of the Saratov Volga region (they are "the image of an object", free composition of elements, building an artificial relief, a lot of scenic points, domination of water bodies);

- Some borrowings from the Chinese art of gardening: a number of greenery kinds, emphasizing the uplands with pavilions and other small buildings with bright colouring (coral red, blue-green, ochre, white), the reflecting effect of water;

- Employing some kinds of greenery plantations of the Chinese origin in Saratov landscaped complexes (introduced plants constitute $20 \%$, including $9.1 \%$ of the Chinese origin; the local flora constitutes about $80 \%$ );

- The amount of evergreen plantations is $15 \%$ in the estate parks of the studied region, and it is $85 \%$ of the deciduous plants (trees and shrubs).

\section{References}

1. E. V. Golosova, Bulletin of the Moscow State Forest University - Forest Bulletin, 1 (2003)

2. E. V. Golosova, Landscape art of China (Natalis, Moscow, 2008)

3. E. V. Golosova, Bulletin of Tomsk State University. Series: Biology, 341 (2010)

4. E.V. Golosova, Problems of formation and formation of East Asian and West European gardens and parks under the influence of the horticultural traditions of China (on the example of China, Japan and Great Britain): the author's abstract of diss. ... the doctors Agricultural Sciences: 06.03.03 (Moscow State Forest University, Moscow, 2011)

5. O. B. Sokolskaya, Bulletin of the Saratov State University named after N. I. Vavilov, 4 (2003)

6. O. B. Sokolskaya, History of landscape art: a textbook for universities ("INFRA-M" Publishing House, Moscow, 2004)

7. O. B. Sokolskaya, I. V. Sergeeva, Proceedings of the conference on the results of scientific research and production work for 2010 (SSAU, 2011)

8. O. B. Sokolskaya, Floriculture, 2 (2012)

9. O. B. Sokolskaya, Garden and park art: formation of development (Publishing House "Lan", St. Petersburg, 2013)

10. O. B. Sokolskaya, Restoration of the objects of the landscape and park heritage of the Volga region in Russia: Theoretical and experimental justification for the revival of "green architecture" on the territory of the Volga Upland (LAP LAMBERT Academic Publishing, Germany, 2014)

11. E. N. Fomenkova, Advances in Contemporary Natural History, 3 (2016) 